\title{
Acquisition and Transfer of Values and Social Skills through a Physical Education Program Focused in the Affective Domain
}

\author{
Pedro Gil-Madrona ${ }^{*}$, Amaury Samalot- Rivera ${ }^{1}$, Francis M Kozub ${ }^{1}$
}

\author{
ORIGINAL ARTICLE
}

\begin{abstract}
The purpose of this study was to examine the effectiveness of a physical education (PE) program focused on the affective domain for 6 th to $8^{\text {th }}$ grade students with respect to the acquisition and transfer of social skills and values. Further, the extent that general classroom teachers and parents perceived if the learned skills where transferred to other context outside the PE class was examined in a sample of 274 students (ages 11 to 13 years old). One hundred and forty-five males $(53 \%)$ and 129 females (47\%) from five urban schools in Albacete Spain were studied. Three questionnaires were used (pre and post rating scales) as data collection instruments for students, teachers and parents. Results demonstrated encouraging estimates of reliability for the subscales of PE teachers' perceptions of students' values and regular education teaches perceptions with very strong values of internal consistency .82 and .93 respectively. Posttest values were slightly higher. Further, findings demonstrated positive outcomes after the intervention in teacher perceptions about students values levels $(t=-8,05 ; p<.01)$, enjoyment, $(t=-7.10 ; p<.01)$, fair play $(t=$ -8.09; $p<.01)$, social relation $(t=-6.48 ; p<.01)$, good habits $(t=-7.43 ; p<.01)$ and emotional control $(t=-6.03 ; p<.01)$ in favor of the intervention group. These results support previous studies evidencing that integrating social skills and values intervention in the PE class increase students' development in the affective domain.
\end{abstract}

Keywords: Values, social skills, fair play, physical education, affective domain, teachers, parents and students.

\section{INTRODUCTION}

The effectiveness of integrating the teaching of social skills and values in the PE context had been studied (Hellison, 2011; Samalot-Rivera \& Porretta, 2012; Vidoni \& Ward, 2009). However, there is not much empirical evidence about its effectiveness beyond the physical education class (Samalot-Rivera \& Porretta, 2009). For purpose of this study, social skills will be defined as socially acceptable behaviors that enable the person to interact with others in ways that elicit positive responses and assist in avoiding negative responses for them (Cartledge \& Milburn, 1995). In other hand, values refer to a set of beliefs that guide the behavior of humans. Values possess a certain level of subjectivity and vary from one culture or group to the other. For example; for some students it is important to embrace the value of fair play when they participate in sports or games but for others winning is more important even if they have to bend the rules (Arruce-Giraldez, 2011). For this reason, researchers believe it is important for all educators including physical educators to implement programs to develop appropriate social skills and values to their students through the PE class (Samalot-Rivera \& Porretta, 2012; Samalot-Rivera, 2013; Shehu, 2010; Sugden, 2006; Torres, 2011).

Social skills instruction is based on Social Learning Theory (Bandura, 1977) which is a proactive, positive intervention designed to replace negative behaviors with more desirable ones and to teach students more constructive socially rewarding ways to behave (Cartledge, Gardner, \& Ford, 2008). Based on social learning

Manuscript received at February $2^{\text {nd }} 2015$; Accepted at October $19^{\text {th }} 2016$

1 Universidad de Castilla La Mancha

* Corresponding Author. Faculdad de Educación de Albacete. Universidad de Castilla La Mancha. España. E-mail: Pedro.Gil@uclm.es 
theory, most behaviors are learned and thus direct instruction can be used to teach appropriate social behaviors (Ormrod, 1999).

Cecchini-Estrada, Montero, and Peña (2009) view fair play as an ideal ethical set of behaviors that can be acquired by participating in sports. Also that these set of behaviors can be transferred to other areas of life outside the gym. However, Hellison (2011) and others (e.g. Samalot-Rivera \& Porretta, 2012; Vidoni \& Ward, 2009) concluded that it is important to take time and explicitly teach social skills and values through the PE class and we should not assumed that students will learn this skills by just participating in the PE class. Samalot-Rivera and Porretta (2012) studied the effectiveness of a social skill curriculum intervention on the acquisition and transfer of appropriate social behaviors through PE on students with emotional disturbance. The intervention consisted of three sets of social skills: appropriate behaviors when winning, appropriate behaviors when loosing and appropriate behaviors during the game. Results demonstrated that the intervention was effective increasing appropriate behavior and decreasing inappropriate ones during PE class. Further, social validity data demonstrated that parents and teachers valued the program intervention. In another study Vidoni and Ward (2009) examined the effects of Fair Play Instruction on middle school physical education classes during a tag rugby unit. The Fair Play intervention consisted of: (a) students developing a chart with fair play cues to be accomplished during the lesson, (b) teacher's prompts and praise during the lesson related to fair play behaviors, and (c) positive pinpointing of fair play behaviors used by students during the lesson closure. Fair Play Instruction was consistently effective in increasing students' active participation, and in decreasing waiting time for all participants. Also it was effective in decreasing the number of harmful behaviors. Further, social validity data from this study provided strong evidence that teachers and students valued the intervention.

The purpose of this study is to examine the effectiveness of PE programming focused on the teaching of social skills and values within the content of fair play, social relations, effort and self-improvement, good manners and self-control on the socio - affective domain of $6^{\text {th }}$ to $8^{\text {th }}$ grade students. It is also trying to determine parents' and teachers' perceptions about the learned skills through the PE class. Further to see if these skills transfer to other contexts outside the class. It was hypothesized that the application of an intervention program focused on social skills and values during the PE class will improve students' behaviors during and after class.

\section{METHODS}

\section{Participants}

Purposeful sampling resulted in $2746^{\text {th }}$ to $8^{\text {th }}$ grade students including 145 (53\%) males and 129 (47\%) females between the ages of 11 and 13 years from five urban schools from Albacete Spain. Informed consent was secured from all five schools, teachers, and parent school council prior to conducting this study.

\section{Intervention and Procedures}

\section{Teacher Training}

Teacher training sessions took place once a week during the time of the investigation. During these training sessions the principal investigator prepared the teachers on how to provide the intervention and collect data. For training purposes, PE teachers recorded students' behaviors fifteen days previous to the intervention via observation with an observation form, analyzed behaviors and come to agreement about scoring criteria.

\section{Intervention}

The intervention consisted of the integration of a set of values and social skills throughout physical education lessons. This intervention was based on previous work by Gil-Madrona (2008) related to the development of values during the physical education class. Intervention and control groups were randomly selected in each school resulting in 274 students from $6^{\text {th }}$ to $8^{\text {th }}$ grade including 145 (53\%) males and 129 (47\%) females between the ages of 11 and 13 years. The intervention was implemented to the experimental group through a period of three months for a total of 24 classes. The control group remained with their established general PE 
programed instruction. The instruction for both groups (intervention and control) in each school was provided by the same PE teacher. The content of the intervention program focused on the education of values. This program is outlined in Figure 1.

Enjoyment: Participation and enjoyment no matter the results of the game.

Effort: desire to become better, respect the opponent, value the effort to become better in motor competency.

Social Relations: make Friends through PE class, be tolerant and humble.

Fair-play: respect to teammates and opponents, respect to officials, learn to be a good winner and to accept when you lose.

Emotional Control: maintain calm on difficult situations, maintains calm and order personally and within the team no matter the result of the game. Also recognize owns errors.

Respect the rules: Accept the rules of games and sports; follow teacher instructions and accept results.

Intervention Techniques: case studies, debates, cooperative investigation, small discussions, problem solving activities, moral dilemmas, values discovery activities, methods of learning values, methods of clarifying values, methods of practice the values in real scenarios.

Figure 1. Teaching Values through Physical Education and Sports (Gil-Madrona, 2008).

\section{Data Collection and Instrument Development}

Three likert scale questionnaires were used (pre and post rating scales) as data collection instruments for students, teachers and parents. First a questionnaire was applied to the students so they could record their own perceptions of their behaviors during the PE class. Also a questionnaire was given to their parents to measure student behaviors in their family environment. Further a questionnaire was given to their general classroom teacher to measure their behaviors outside the physical education classroom in the school context. All this was done before and after the intervention to measure the effectiveness of it.

The instruments (likert scale questionnaires) were developed by the research team based on the work of Rokeach (1973), Lee and Cook (1990), Lee, Whitehead and Balchin (2000), Escartí (2005), Carranza and Mora (2003), Marchant and Pérez (2008), and Josephson (2010). Instruments were revised and content validated by a group of experts from other universities from Spain and the United States.

The questionnaire used for the study provided a range of values for each item between 1 to 5 . The content of the items are found in Figure 1.
Evidence for subscale internal consistency included moderate to very strong values. Alpha coefficients resulted in values for student selfperceptions $(\alpha=.60)$, parent perceptions about students' values $(\alpha=.56)$, physical educators' perceptions of students' values $(\alpha=.82)$, and regular educators' perceptions $(\alpha=.93)$ that were varied in magnitude. Values show that all subscales resulted in moderate to very strong estimates of reliability for these data. Specifically, with respect to responses from students and parents, the rating scales resulted in only moderate alpha coefficients with these values improving somewhat from post test estimates.

\section{Data Analysis}

Descriptive statistics were calculated for these data initially. This was followed by an examination of alpha coefficients to estimate reliability of scales. To examine data further, Pearson correlation was used to study relationships between sub scales. Further, t tests were used to make inferences relative to the tested hypotheses. These included examination of pre and post evaluations for the different considered variables: students self-reports of values, the perception of students values from the 
physical education teacher, the perception of students values from the regular classroom teacher and the perception of students values from parents. Every specific values was calculated (fun, fair play, positive social relations, emotional control, effort and good habits) going from the score averages from each instrument followed by other four global measurements obtaining final variables used for the analysis.

Table 1.

Descriptive Pre and Post Measures of Instruments

\begin{tabular}{lccc}
\hline & & Pre & Post \\
\hline Self-report of values & Control & $3.57 \pm 0.49$ & $3.83 \pm 0.50$ \\
(Students) & Intervention & $3.83 \pm 0.43$ & $3.86 \pm 0.51$ \\
\hline Values Perceptions (PE teachers) & $3.34 \pm 0.71$ & $4.54 \pm 0.44$ \\
\hline Values Perceptions (General Teacher) & $2.86 \pm 0.52$ & $4.22 \pm 0.52$ \\
\hline Values Perceptions (Parents) & $4.04 \pm 0.30$ & $4.10 \pm 0.26$ \\
\hline
\end{tabular}

Correlation measures estimated relationships between variables. PE teachers and students with $(r=.30, p<.01)$, PE teacher and general teachers with $(r=.51, \mathrm{p}<.01)$, PE teacher and parents with $(r=0.13, \mathrm{p}>.01)$, general teachers and parents with $(r=.26, p<.01)$, general teachers and students with $(r=.34, p<.01)$ and students and parents with $(r=.34, p<.01)$.

Global measures of $\mathrm{T}$ test were compared (students, physical education teacher, regular classroom teachers and parents). Results for the control group were not significant (pre and post test). However, in the intervention group there is a significant improvement on PE perceptions about students values levels $(t=-8.05 ; p<.01)$. Meanwhile students perceptions $(t=-0.62 ; p>$ $.05)$, regular teacher perceptions $(t=-0.71 ; p>$ $.05)$ and parents perceptions $(t=0.97 ; p>.05)$ the intervention was not significant.

The perception of physical education teachers had the following significant scores in the intervention group in relation to the values of enjoyment $(t=-7.10 ; p<.01)$, fair play $(t=$ 8.09; $p<.01)$, social relation $(t=-6.48 ; p<.01)$, good habits $(t=-7.43 ; p<.01)$ y emotional control $(t=-6.03 ; \mathrm{p}<.01)$. In the control group there was no significant within group differences on values of enjoyment, fair play, good habits and social relations. But there are significant differences on the values of effort $(t=2.86 ; p<$

\section{RESULTS}

Results are presented in three different areas: descriptive (table 1), correlational and $\mathrm{T}$ test for physical education teachers. Table 1 descriptive results demonstrate measures close to 4 to 5 , on a scale from 1 to 5 . All instrument measures demonstrate increases from pre to post test in the intervention group. PE and general teacher perceptions obtained the highest post test scores with 4.54 and 4.22 respectively.
.01) that we can interpreted that the intervention did had an effect on this results; and emotional control $(t=2.86 ; p<.01)$ that can be explained due to the psychological maturation of the students in both the intervention and control group; but with the intervention this value increase.

\section{DISCUSSION AND CONCLUSION}

There had been some intervention programs for development of values in physical activity and sport contexts like (Shields \& Bredemeier, 1995; Weiss \& Smith ,2002), "Fair-play for children», (Gibbons, Ebbeck, \& Weiss, 1995; Wandzilak, Caroll, \& Ansorrge, 1988); «Development of Life Abilities» (Danish \& Nellen, 1997); «Personal and Social Responsibility» (Hastie \& Buchanan,2000; Hellison,2011); «Moral Development" (Miller, Bredemeier, \& Shields, 1997); and «Sport for Peace» (Ennis et al., 1999), «Fair Play Code of Conduct» (Siedentop, Hastie \& Van der Mars, 2004) "Appropriate Behavior Through Physical Education and Sport Curriculum» (Samalot-Rivera, 2007), among others.

In Spain, every day teachers are implementing programs to develop "appropriate behaviors" using $\mathrm{PE}$ and sport as resources for the development of those values, moral development and personal and social responsibility (Cecchini, 
Fernández-Losa \& González, 2008; Gil-Madrona, 2008; Gutiérrez \& Vivó, 2002), obtaining positive results.

In the present study that evolve from a holistic evaluation, it is observed that those groups that intervention is not used (a program on teaching values and appropriate behavior through physical education) there is not significant improvements on behaviors. There is no significant difference in values when comparing pre and posttest scores in any of the four different instruments. On the other hand, evidence is provided of the effectiveness of intervention and improvement in social skills for the group that received the intervention. This results support previous research that demonstrate that students benefit and improve in their social behaviors during the physical education class when interventions are implemented (Madrid-Lopez, Prieto-Ayuso, Samalot-Rivera, \& Gil-Madrona, 2016; SaizPanadero, Prieto-Ayuso, Gutierrez-Marín, \& GilMadrona, 2016; Samalot-Rivera \& Porretta, 2012; Vidoni \& Ward, 2009).

In relation to transfer the learned values in physical education to other context, this can but students need to be willing to do that (Escartí, Pacual, \& Gutiérrez, 2005; Hellison, 2011; Tomporowski, Davis, Miller, \& Naglieri, 2008; Shehu, 2010). In this study the transfer of learned values and behaviors for the intervention group is not noticed by parents and general classroom teacher. The average scores in values between the POST scores are significantly higher than the average scores for PRE for the intervention group in all four estimations (with students, with PE teacher, with general teacher and parents). Changes are generally produced in the PE classes and there is no transfer of the acquired values to other social context. This mean that general teacher and parents did not perceived with the same intensity the changes that the PE teachers reported in their classes. Also support previous findings about the difficulty of transferring learned appropriate behaviors in PE class to other context if follow up or collaboration between teachers and parents is not in place (SamalotRivera \& Porretta, 2012).

This study also reveals two subscales with encouraging estimates of reliability to measure social skills development in the school context. The results of this study confirm results from other previous studies in terms of the $\mathrm{PE}$ perceptions of the values their students gain through the intervention related to social skills and values, moral reasoning (Gutierrez \& Vivó, 2002; Russell, 2011; Wandislak, Carrol \& Ansorge, 1988), social competences (Danish \& Nellen, 1997; Skinner, Zakus, \& Cowell, 2008), disruptive behaviors on (Ennis et al., 1999; Samalot-Rivera, 2007), and social responsibility (Cecchini, Montero, \& Peña, 2003; Escartí, Pacual, \& Gutiérrez, 2005; Gil-Madrona, 2003).

The application of the PE and sport program improved the development of each one of the variables in the intervention group. However, for the variable of self-control there were differences in both groups. The explanation for this to happen also in the control group is basically due to maturity process and part of the structure provided by the teacher during the PE class. However, better results were obtained in the intervention group.

In summary we can conclude that when a social skills and values intervention in the $\mathrm{PE}$ class is implemented, students increase their knowledge about how to behave increasing positively their overall experience in the PE class. Also that the behaviors acquired through the PE class intervention can be transferred to some extent to other environments. Future research in this topic should focus on effective ways to increase the generalization of the learned behaviors to other settings in and outside the school setting.

\section{Acknowledgments:}

Nothing to declare

Conflict of interest:

Nothing to declare

Funding:

Nothing to declare 


\section{REFERENCES}

Arrufe-Giraldes, V. (2011). La educación en valores en el aula de Educación Física. ¿Mito o realidad? EmásF. Revista Digital de Educación Física, 9, 111.

Bandura, A. (1977). Social learning theory. Englewood Cliffs, N. J.: Prentice Hall.

Carranza, M., \& Mora, J. M. (2003). Educación física y valores: Educando en un mundo complejo. Barcelona: Graó.

Cartledge, G., Gardner, R., \& Ford, D. Y. (2009). Diverse Learners with Exceptionalities: Culturally Responsive Teaching in the Inclusive Classroom. Pearson.

Cartledge, G., \& Milburn, J. F (1995). Teaching social skills to children and youth: Innovative approaches ( $3^{\text {rd }}$ ed.). Boston: Allyn \& Bacon

Cecchini-Estrada, J. A., González de Mesa, C., AlonsoGonzález, C., Berreal-San Martín, J. M., Fernández-Gutiérrez, C., García-Viejo, M., Llaneza-Lobo, R., \& Nuño-Iglesias, P. (2009). Repercusiones del Programa Delfos sobre los niveles de agresividad en el deporte y otros contextos de la vida diaria. Apunts, 96, 34-41.

Cecchini-Estrada, J. A., Montero, J., \& Peña, V. (2003). Repercusiones del Programa de Intervención para Desarrollar la Responsabilidad Personal y Social sobre los comportamientos de fair-play y el autocontrol. Psicothema, 15, 631-637.

Cecchini-Estrada, J. A., Fernández- Losa, J., \& González, C. (2008). Repercusiones del Programa Delfos de educación en valores a través del deporte en jóvenes escolares. Revista de Educación, 346, 167-186.

Danish, S., \& Nellen, V. C. (1997). New roles for sport psychologists: Teaching life skills through sport to at-risk youth. Quest, 49, 100-113.

Ennis, C. D., Solmon, M. A., Satina, B., Loftus, S. J., Mensch, J., \& McCauley, M. T. (1999). Creating a sense of family in urban schools using the Sport for Peace curriculum. Research Quarterly for Exercise and Sport, 70, 273-285.

Escartí, A. (2005). Utilización del deporte y la actividad física como herramienta para enseñar responsabilidad personal y social a niños/as en edad escolar. Primer Congreso Deporte en edad escolar. Valencia. Adjuntamente de Valencia y Fundación Deportiva Municipal.

Escartí, A., Pacual, C., \& Gutiérrez, M. (2005). Responsabilidad personal y social a través de la educación física y el deporte. Barcelona: Graó.

Gibbons, S. L., Ebbeck, V., \& Weis, M. R. (1995). Fair play for kids: Effects of moral development of children in physical education. Research Quarterly for Exercise and Sport, 66, 247-255.

Gil-Madrona, P. (2003). Diseño y desarrollo curricular en educación física y educación infantil. Sevilla: Wanceulen.

Gil-Madrona, P. (Cord) (2008). La Educación Física y los deportes: Concreciones prácticas de educación en valores (Ediciones Mágina). Granada: Editorial Octaedro Andalucía.
Gutiérrez, M., \& Vivó, P. (2002). Desarrollo sociomoral en Educación Física. VII Congreso AEISAD. Gijón.

Hastie, P.A., \& Buchanan, A.M. (2000). Teaching responsibility through sport education: Prospects of a coalition. Research Quarterly for Exercise and Sport, 71, 25-36.

Hellison, D. R. (2011). Teaching personal and social responsibility through physical activity ( $3^{\text {rd }}$ ed.). Champaign, IL: Human Kinetics.

Josephson, M. (2010). Un estudio sobre los valores en Puerto Rico. Josephson Institute. Recuperado de: http://josephsoninstitute.org/pdf/report_puerto -rico_values-survey_2010.pdf

Lee, M., \& Cook, C. (1990). Review of the literature on fairplay with special reference to children's sport. Comunicación presentada al Council of Europe Meeting on Fairplay in Children's Sport. Paris: Noviembre 1989

Lee, M. J., Whitehead, J., \& Balchin, N. (2000). The Measurement of Values in Youth Sport: Development of the Youth Sport Values Questionnaire. Journal of Sport and Exercise Psychology, 22(4), 307-326. https://doi.org/10.1123/jsep.22.4.307

Madrid-Lopez, P., Prieto-Ayuso, A., Samalot-Rivera, A., \& Gil-Madrona, P. (2016). An extracurricular proposal for the promotion of appropriate attitudes in physical education and sports. Retos, 30, 36-43.

Marchant, J., \& Pérez, A. (2008). Transversalidad y valores en el desarrollo del currículum y la evaluación. La evaluación de actitudes y valores. Universidad de Santiago de Chile. Facultad de humanidades. Magister en educación.

Miller, S., Bredemeier, B., \& Shields, D. (1997). Sociomoral education through physical education with at-risk children. Quest, 49, 114-129.

Ormrod, J. E. (1999). Human Learning (3 ${ }^{\text {rd }}$ ed.). Upper Saddle River, N. J.: Merrill Prentice Hall.

Rokeach, M. (1973). The Nature of Human Values. New York: Free Press.

Russel, J. S. (2011). The Moral Ambiguity of Coaching Youth Sport. Em A. R. Hardman \& C. Jones (Eds.), The Ethics of Sports Coaching (pp. 87103). Oxon: Routledge.

Saiz-Panadero, M., Prieto-Ayuso, A., Gutiérrez-Marín, E. C., \& Gil-Madrona, P. (2016). Initial evaluation in 6th grade elementary teaching social skills and intervention approach school physical education. SporTK: Revista Euroamericana de Ciencias del Deporte, 5(1), 65-74.

Samalot-Rivera, A., \& Porretta, D. L. (2012). The influence of social skills instruction on sport and game related behaviors of students with emotional or behavioral disorders. Physical Education and Sport Pedagogy, 17, 1-16.

Samalot-Rivera, A. (2007). The effects of a social skill instruction on the sport and game related behaviors of children and adolescents with emotional or behavioral disabilities (Doctoral 
Dissertation). The Ohio State University, Columbus, $\mathrm{OH}$.

Samalot-Rivera, A. (2013). Modelos a utilizar para la enseñanza de valores y destrezas sociales apropiadas en la Educación Física y el Deporte: una revisión de literatura. EFDeportes, 184. Retrieved from

http://www.efdeportes.com/efd184/laensenanza-de-valores-y-destrezas-sociales.htm

Shehu, J. (2010). Football for Hope Centres in Africa: Intentions, Assumptions and Gendered Implications. In J. Shehu (Ed.), Gender, Sport and Development in Africa: Cross-Cultural Perspectives on Patterns of Representation and Marginalization (pp. 135-154). Dakar, SEN: Counsel for the Development of Social Science Research in Africa.

Shields, D., \& Bredemeier, B. (1995). Character development and physical activity. Champaign, IL: Human Kinetics.

Siedentop, D., Hastie, P.A., \& Van der Mars, H. (2004). Complete guide to sport education ( $2^{\text {nd }}$ ed.). Champaign, IL: Human Kinetics.

Skinner, J., Zakus, D., \& Edwards, A. (2008). Coming in From the Margins: Ethnicity, Community Support, and the Rebranding of Australian Soccer. Soccer and Society, 9(3) 394-404.
Sugden, J. (2006). Teaching and Playing Sport for Conflict Resolution and Co-existence in Israel. International Review for the Sociology of Sport, 41(2), 221-240.

Tomporowski, P. D., Davis, C. L., Miller, P. H., \& Naglieri, J. A. (2007). Exercise and Children's Intelligence, Cognition, and Academic Achievement. Educational Psychology Review, 20(2), $111-131$. https://doi.org/10.1007/s10648-007-9057-0

Torres, C. (2011). Morally Incompatible? An Analysis of the Relationship between competitive sport and international relations at the Olympic Games. SAIS Review, 31(1), 3-16.

Vidoni, C., \& Ward, P. (2009). Effects of fair play instruction on student social skills during a middle school sport education unit. PhysicalEducation \& Sport Pedagogy Journal, 14(3), 285-310.

Wandzilak, T., Carroll, T., \& Ansorge, C. J. (1988). Values development through physical activity: Promoting sportmanlike behaviors, perceptions, and moral reasoning. Journal of Teaching in Physical Education, 8(1), 13-22.

Weiss, M.R., \& Smith, A.L. (2002). Friendship quality in youth sport: Relationship to age, gender, and motivation variables. Journal of Sport \& Exercise Psychology, 24, 420-437. otherwise specified and in content retrieved from other bibliographic sources. 